\title{
Vochysia tucanorum Mart.: an aluminum-accumulating species evidencing calcifuge behavior
}

\author{
Marcelo Claro de Souza (1D - Gustavo Habermann - Cárita Liberato do Amaral • \\ Annylory Lima Rosa • Marcelo Henrique Ongaro Pinheiro • Fernando Batista Da Costa
}

Received: 23 March 2017 / Accepted: 20 July 2017 / Published online: 26 July 2017

(C) Springer International Publishing AG 2017

\begin{abstract}
Background and aims Acidic soil occupies $30 \%$ of the world's ice-free land, and exchangeable aluminum (Al) availability increases under these conditions, being toxic to many plant species. However, some plants accumulate Al without damage to their metabolism. Vochysia tucanorum is an Al-accumulating species endemic to the cerrado vegetation with acidic soils in South America. Here, we predict that it is a calcifuge species. Methods We assessed macro and micronutrient concentrations as well as $\mathrm{Al}$ accumulation, plant height and root length of potted plants grown on acidic and calcareous soil for 60 days. A LC-MS-based metabolite fingerprinting of plants on both conditions was also performed.
\end{abstract}

Responsible Editor: Juan Barcelo.

M. C. de Souza $(\bowtie) \cdot$ A. L. Rosa • F. B. Da Costa

AsterBioChem research team, School of Pharmaceutical Sciences of Ribeirão Preto, University of São Paulo (USP), Av. do Café s/n, Monte Alegre, Ribeirão Preto, SP 14040-903, Brazil

e-mail: marcelo.claro.souza@gmail.com

G. Habermann

Institute of Biosciences, São Paulo State University (UNESP), Av. 24-A, 1515, Rio Claro, SP 13506-900, Brazil

C. L. do Amaral

School of Agricultural and Veterinarian Sciences, São Paulo State University (UNESP), Via de Acesso Prof. Paulo Donato

Castelane, s/n, Jaboticabal, SP 14884-900, Brazil

M. H. O. Pinheiro

Federal University of Uberlandia (UFU), Rua 20, 1600, Ituiutaba, MG 38304-402, Brazil
Results Plants grown on acidic soil showed higher biomass and $\mathrm{Al}$ concentration in roots and shoots than those grown on calcareous soil. Despite the higher concentration of macronutrients on plants grown on calcareous soil, micronutrients concentration was similar between plants grown on these soils. Plants grown on the calcareous soil showed necrotic leaves. The metabolite fingerprinting indicated significant changes in the metabolism of phenolics and organic acids.

Conclusions Due to the high $\mathrm{Al}$ accumulation in plants grown on acidic soil, and their inability to survive in calcareous soil, we conclude that V. tucanorum is an Alaccumulating species with calcifuge behavior.

Keywords Cerrado woody species - Intolerance to calcareous soil $\cdot$ LC-MS · Seedling growth . Vochysiaceae

\section{Introduction}

Symptoms of nutritional disorders often occur when plants face unfavorable environmental conditions, one of the most serious resulting from soil acidity, which occurs in approximately $30 \%$ of the world's ice-free land (von Uexküll and Mutert 1995; Kochian et al. 2015). In acidic soils from tropical and temperate climates, aluminum minerals are solubilized to $\mathrm{Al}^{3+}$ and related oxides and hydroxides, which are toxic forms to many plant species (Kochian et al. 2004; Kochian et al. 2015). 
In sensitive species, soluble aluminum reduces plant growth and causes stunted roots (Horst et al. 2010). Alinduced decreases in root growth can be observed within hours in herbaceous plants (Kopittke et al. 2008) or days in woody species (Banhos et al. 2016a, b). As most Al covalently binds to the cell wall of root cells (Horst et al. 2010), there is a debate in the literature on whether nutritional disorders observed in shoots and leaves are direct or indirect effects of Al. To deal with Al toxicity, Al-excluding species release organic acids from roots, therefore detoxifying $\mathrm{Al}$ in the rhizosphere by Alorganic acid complexes (Ryan et al., 2011). On the other hand, Al-accumulating species increase $\mathrm{Al}$ uptake and promote sequestration of $\mathrm{Al}$ to cell compartments (Brunner and Sperisen 2013). Both mechanisms have been described in herbaceous and wood species (Ryan et al. 2011; Brunner and Sperisen 2013).

Species that naturally grow on acidic soils are expected to have natural resistance to Al. Symplocos paniculata (Thunb.) Miq. (Symplocaceae), native to temperate climates in Asia, shows increased biomass in the presence of $\mathrm{Al}$ in a nutrient solution (Schmitt et al. 2016). In the tropics, various woody species from the vegetation type called Cerrado (broadly known as 'Brazilian savanna') also grow well on acidic $(\mathrm{pH} \approx 4.0)$ soils that are rich in exchangeable and soluble $\mathrm{Al}$ from oxisoils from Central Brazil (Haridasan 2008). Alaccumulating species can store between 1000 and $>15,000 \mathrm{mg} \mathrm{Al}$ per kg dry leaves, including species from temperate and tropical climates (Haridasan 1982; Metali et al. 2012; Schmitt et al. 2016). Alaccumulating plants from the Cerrado include mainly species from Melastomataceae, Rubiaceae and Vochysiaceae families (Haridasan 1982; Souza et al. 2015b; Bressan et al. 2016).

Changes in the metabolome usually occur after disturbances of any kind are imposed on plants (Fukusaki and Kobayashi, 2005). Thus, any stress experienced by plants may affect their metabolome (Obata and Fernie 2012; Sampaio et al. 2016). Despite the large number of secondary metabolites described for Vochysiaceae species from the Cerrado (Carnevale-Neto et al. 2011), many of them are still unknown, and as far as we are aware, metabolomic profiles of Al-accumulating plants have never been studied, especially when under different growth conditions. In the last years, the use of liquid chromatography coupled to mass spectrometry (LCMS) increased significantly, therefore, easily enabling the detection of plant secondary metabolites (Sampaio et al. 2016; Simirgiotis et al. 2016). Metabolomic profiles may represent a primary approach when aiming to detect different group of compounds biosynthesized under distinct conditions. It also requires the use of multivariate statistical analysis and natural product databases (Wolfender et al. 2013).

In this context, we elected an Al-accumulating woody species, Vochysia tucanorum Mart. (Vochysiaceae) endemic in the cerrado vegetation in South America. It grows well on acidic $(\mathrm{pH} \approx 4.0$ ) oxysoils that are rich in exchangeable (and soluble) Al. It occurs in vegetation physiognomies described as cerrado sensu stricto, which is a typical savanna-type vegetation, cerradão (augmentative of 'cerrado' in Portuguese and it refers to a dense wood savanna) and riparian forests (Haridasan and Araújo 1988; Barbosa et al. 1999; Ratter et al. 2003). This distribution suggests that $V$. tucanorum is a calcifuge species that does not tolerate calcareous soil, as evidenced for other species (Haridasan 1988; Lee 1998; Haridasan 2008), and we also investigate whether this behavior is present in the early development phase of this species. We assessed plant height, root length, as well as $\mathrm{Al}$, macro and micronutrient accumulation and LC-MS-based metabolite fingerprinting of $V$. tucanorum seedlings grown on acidic and calcareous soils.

\section{Material and methods}

Plant material and experimental design

Seeds of $V$. tucanorum were collected in September 2014 at a cerrado sensu stricto reserve within the Estação Ecológica de Mogi Guaçu (Mogi Guaçu, SP, Brazil) $\left(22^{\circ} 15^{\prime} \mathrm{S}, 47^{\circ} 00^{\prime} \mathrm{W} ; 22^{\circ} 30^{\prime} \mathrm{S}, 47^{\circ} 15^{\prime} \mathrm{W}\right)$. The seeds were sterilized with $5 \%$ sodium hypochlorite (for $10 \mathrm{~min}$ ), washed in tap water (for $10 \mathrm{~min}$ ) and allowed to germinate on two layers of filter paper (moistened with deionized water) inside germination boxes. These boxes were maintained in the dark inside germination chambers at $25{ }^{\circ} \mathrm{C}$ for 15 days (Barbosa et al. 1999). Five days after germination, seedlings with $1 \mathrm{~cm}$ roots were transferred to trays containing an organic substrate, Plantmax ${ }^{\circledR}$ (Campinas, SP, Brazil), from which $\mathrm{Al}$ was absent. The seedlings grew in these trays inside a greenhouse for 30-40 days until exhibiting fully expanded cotyledons before transfer to pots containing a range of soil types. Before transplanting them, 
their roots were gently washed with tap water to remove debris. Ninety seedlings were used for each treatment (soil type). A single seedling per pot was used, and the pots stayed on benches, randomly distributed inside the greenhouse.

For 60 days (Dec/2014 to Feb/2015), the plants grew in pots $(2.5 \mathrm{~L})$ containing quartzipsamment soil (here named acidic soil) and ustorthent soil (here named calcareous soil) (USDA 1999). These soil types were collected from the first $30 \mathrm{~cm}$ depth from two cerrado reserves in Brazil. The acidic soil was found in a cerrado sensu stricto reserve in the municipality of Itirapina $\left(22^{\circ} 13^{\prime} \mathrm{S}, 47^{\circ} 53^{\prime} \mathrm{W}\right), \mathrm{SP}$, Brazil. The calcareous soil occurred in a cerrado vegetation in the municipality of Ituiutaba $\left(19^{\circ} 06^{\prime} \mathrm{S}, 49^{\circ} 25^{\prime} \mathrm{W}\right), \mathrm{MG}$, Brazil. The soils were dried in the shade under room temperature and sieved $(0.5 \mathrm{~cm})$ to remove pebbles, leaves and unwanted material. Soil $\mathrm{pH}$ was determined in $\mathrm{CaCl}_{2}$, and $\mathrm{P}$ content was determined by spectrophotometry after anion exchange resin extraction. Cations and micronutrients were extracted with $1.0 \mathrm{M} \mathrm{KCl}$ and determined by EDTA complexometry (Raij et al. 1987). Aluminum was determined by $\mathrm{NaOH}$ titration (Raij et al. 1987).

The acidic and calcareous soils showed the same organic matter content, but the soil fertility parameters were significantly different between them. The $\mathrm{pH}$ in the acidic soil was lower than 4.0, while in the calcareous soil it was 6.2; base saturation (BS) and the cation exchange capacity (CEC) were 30 and 1.7 times higher in the calcareous soil when compared to the acidic soil, respectively (Table 1 ). While no exchangeable $\mathrm{Al}$ was found in the calcareous soil, $68 \%$ of the CEC of the acidic soil was Al (Table 1). Nutrient availability was also higher in the calcareous soil in comparison to the acidic soil: $+70 \% \mathrm{P},+73 \% \mathrm{~K},+97 \% \mathrm{Ca},+95 \% \mathrm{Mg}$, $+82 \% \mathrm{Zn}$, and $+62 \% \mathrm{Mn}$. On the other hand, the acidic soil had $80 \%$ more Fe (Table 1).

\section{Plant development}

At 30, 45 and 60 days after planting (DAP), for each soil type, 15 randomly selected individuals were used to determine the number of leaves, leaf area $\left(\mathrm{cm}^{2}\right)$, plant height $(\mathrm{cm})$, length of taproots $(\mathrm{cm})$, and root and shoot biomass (mg). To keep the root system as undamaged as possible, plants were removed from the pots with clods and displaced on a sieve so that the soil could be gently removed with tap water. After separating the plant organs, the leaf area was determined using a model to
Table 1 Chemical analysis of the acidic (quartzipsamment) and calcareous (ustorthent) soils used in this study $(n=4)$

\begin{tabular}{llll}
\hline & Acidic soil & Calcareous soil & $P$ \\
\hline $\mathrm{pH}\left(\mathrm{in} \mathrm{CaCl}_{2}\right)$ & $3.51 \pm 0.07$ & $6.28 \pm 0.06$ & $<0.0001$ \\
$\mathrm{OM}\left(\mathrm{g} \mathrm{dm}^{-3}\right)$ & $44.24 \pm 3.21$ & $45.75 \pm 3.68$ & $\mathrm{~ns}$ \\
$\mathrm{P}\left(\mathrm{mg} \mathrm{dm}^{-3}\right)$ & $9.85 \pm 2.79$ & $32.48 \pm 5.19$ & $<0.001$ \\
$\mathrm{~K}\left(\mathrm{mmol}_{\mathrm{c}} \mathrm{dm}^{-3}\right)$ & $0.99 \pm 0.11$ & $3.77 \pm 0.12$ & $<0.0001$ \\
$\mathrm{Ca}\left(\mathrm{mmol}_{\mathrm{c}} \mathrm{dm}^{-3}\right)$ & $3.33 \pm 0.58$ & $129.67 \pm 1.53$ & $<0.0001$ \\
$\mathrm{Mg}\left(\mathrm{mmol}_{\mathrm{c}} \mathrm{dm}^{-3}\right)$ & $1.81 \pm 0.09$ & $35.67 \pm 0.58$ & $<0.0001$ \\
$\mathrm{Al}\left(\mathrm{mmol}_{\mathrm{c}} \mathrm{dm}^{-3}\right)$ & $13.73 \pm 1.27$ & $0.17 \pm 0.15$ & $<0.01$ \\
$\mathrm{H}+\mathrm{Al}\left(\mathrm{mmol}_{\mathrm{c}} \mathrm{dm}\right.$ & $109.00 \pm 1.00$ & $16.28 \pm 0.80$ & $<0.0001$ \\
$\mathrm{Fe}\left(\mathrm{mg} \mathrm{dm}^{-3}\right)$ & $111.66 \pm 4.40$ & $23.96 \pm 1.02$ & $<0.0001$ \\
$\mathrm{Mn}\left(\mathrm{mg} \mathrm{dm}^{-3}\right)$ & $3.56 \pm 0.38$ & $9.49 \pm 0.52$ & $<0.0001$ \\
$\mathrm{Zn}\left(\mathrm{mg} \mathrm{dm}^{-3}\right)$ & $1.73 \pm 1.16$ & $10.0 \pm 0.30$ & $<0.0001$ \\
$\mathrm{BS}\left(\mathrm{mmol}_{\mathrm{c}} \mathrm{dm}^{-3}\right)$ & $6.32 \pm 0.68$ & $188.43 \pm 6.05$ & $<0.0001$ \\
$\mathrm{CEC}\left(\mathrm{mmol}_{\mathrm{c}} \mathrm{dm}^{-3}\right)$ & $115.32 \pm 0.54$ & $204.76 \pm 5.75$ & $<0.001$ \\
$\mathrm{M}(\%)$ & $68.34 \pm 3.52$ & $0.00 \pm 0.00$ & $<0.0001$ \\
\hline
\end{tabular}

estimate the leaf area of Vochysiaceae as proposed by Souza et al. (2015a). A digital caliper was used for biometrical measurements. Roots and shoots (leaves, petioles and stems) were separated, sampled and ovendried at $60{ }^{\circ} \mathrm{C}$ for $72 \mathrm{~h}$ to determine the biomass.

Nutrient and $\mathrm{Al}$ accumulation

After measuring the biomass of organs at $60 \mathrm{DAP}$, root and shoot samples were powdered using a pestle in a mortar with liquid nitrogen. The samples were digested in 5:1 nitric:perchloric acids. The concentrations of $\mathrm{P}, \mathrm{K}$, $\mathrm{Ca}, \mathrm{Mg}, \mathrm{Fe}, \mathrm{Mn}, \mathrm{Zn}$ and $\mathrm{Al}$ were determined by inductively coupled plasma mass spectrometry (ICP-MS) (Leman Labs). Nitrogen was not determined due to a lack of sufficient plant material.

\section{LC-MS-based metabolite fingerprinting}

At 30, 45 and 60 DAP, three shoot and root samples (obtained as described before) were wrapped in aluminum foil and immersed in liquid nitrogen. After freezing, the samples were ground in a porcelain mortar with pestle. Twenty milligrams of each sample were extracted in $1 \mathrm{~mL}$ of $80 \%$ ethanol (v:v) in an ultrasonic bath (10 min) and centrifuged at 14,000 g (15 min). We added $1 \mathrm{~mL}$ of $95 \% n$-hexane (HPLC grade) to the supernatant and centrifuged it at 14,000 $\mathrm{g}$ (20 $\mathrm{min})$. 
Table 2 Early development of Vochysia tucanorum on acidic and calcareous soils from the cerrado at 30, 45 and 60 days after planting (DAP) $(n=15)$

\begin{tabular}{|c|c|c|c|}
\hline & 30 DAP & 45 DAP & 60 DAP \\
\hline \multicolumn{4}{|c|}{ Number of leaves (plant) } \\
\hline Acidic soil & $2.00 \pm 0.00 \mathrm{a}$ & $5.60 \pm 2.61 \mathrm{~ns}$ & $5.20 \pm 0.84 \mathrm{a}$ \\
\hline Calcareous soil & $0.00 \pm 0.00 \mathrm{~b}$ & $2.90 \pm 1.02$ & $3.60 \pm 0.89 b$ \\
\hline \multicolumn{4}{|l|}{ Leaf area $\left(\mathrm{cm}^{2}\right)$} \\
\hline Acidic soil & $0.54 \pm 0.26 \mathrm{a}$ & $13.44 \pm 6.75 \mathrm{a}$ & $10.98 \pm 3.03 \mathrm{a}$ \\
\hline Calcareous soil & $0.00 \pm 0.00 \mathrm{~b}$ & $2.44 \pm 0.52 b$ & $1.34 \pm 0.91 b$ \\
\hline \multicolumn{4}{|l|}{ Taproot length (cm) } \\
\hline Acidic soil & $5.44 \pm 1.39 \mathrm{~ns}$ & $10.14 \pm 1.45 \mathrm{~ns}$ & $13.25 \pm 2.95 \mathrm{~ns}$ \\
\hline Calcareous soil & $5.20 \pm 1.09$ & $8.54 \pm 0.93$ & $12.50 \pm 2.07$ \\
\hline \multicolumn{4}{|l|}{ Plant height (cm) } \\
\hline Acidic soil & $2.66 \pm 0.67 \mathrm{~ns}$ & $6.10 \pm 0,91 \mathrm{a}$ & $5.55 \pm 1.11 \mathrm{a}$ \\
\hline Calcareous soil & $3.00 \pm 0.62$ & $4.71 \pm 0.49 b$ & $3.53 \pm 0.59 b$ \\
\hline \multicolumn{4}{|l|}{ Root biomass (mg) } \\
\hline Acidic soil & $5.26 \pm 3.95 \mathrm{~ns}$ & $22.80 \pm 8.76 \mathrm{a}$ & $31.55 \pm 6.28 \mathrm{a}$ \\
\hline Calcareous soil & $3.50 \pm 0.64$ & $11.03 \pm 2.04 b$ & $13.78 \pm 3.77 b$ \\
\hline \multicolumn{4}{|l|}{ Shoot biomass (mg) } \\
\hline Acidic soil & $22.8 \pm 5.17 \mathrm{~ns}$ & $111.20 \pm 42.50 \mathrm{a}$ & $95.53 \pm 13.70 \mathrm{a}$ \\
\hline Calcareous soil & $19.8 \pm 2.55$ & $49.34 \pm 5.15 b$ & $37.70 \pm 9.72 b$ \\
\hline
\end{tabular}

$n s$ not significant; different letters indicate significant difference using a $t$-test at $5 \%$

The hydroalcoholic fraction was collected and dried using a speed vacuum concentrator to give the corresponding extracts (Rosa AL, unpublished data).

Each extract was then diluted in acetonitrile:water (1:1 $\mathrm{v}: \mathrm{v})+0.05 \%$ formic acid and filtered through a $0.22-\mu \mathrm{m}$ PTFE membrane (Millipore). The final concentration of each extract was $1 \mathrm{mg} \mathrm{mL}^{-1}$. The samples were injected into an UHPLC-DAD-(ESI)-HRMS system powered with Orbitrap technology (Thermo Scientific) using a
Kinetex xb-C18 column (Phenomenex) and a gradient elution method. Eluent " $A$ " was composed of ultrapure water with $0.05 \%$ formic acid (v:v), and eluent "B" was composed of acetonitrile (LC-MS grade, JT Baker) with $0.05 \%$ formic acid (v:v). The volume of injection was $4 \mu \mathrm{L}$. For the mass data acquisition, we performed a full scan in the positive and negative modes using spray voltages of 3.6 and $3.2 \mathrm{kV}$ (positive and negative modes, respectively), heater temperature of $300{ }^{\circ} \mathrm{C}$, capillary
Fig. 1 Seedlings of Vochysia tucanorum grown on acidic and calcareous soils from the cerrado at 30,45 and 60 days after planting (DAP)
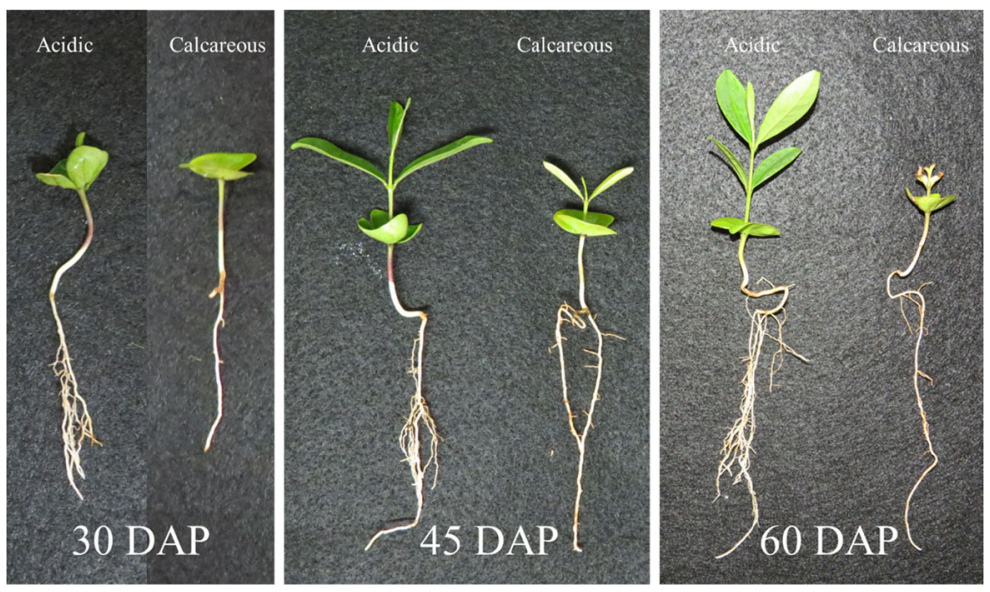
temperature of $320^{\circ} \mathrm{C}$, sheath gas at 30 (arbitrary unity) and aux gas at 11 (arbitrary unity) for both positive and negative modes (Rosa AL, unpublished data). MZmine 2.21 (MZmine project) was used to deconvolute the chromatograms, align the peaks and extract the peak areas (Pluskal et al. 2010; Sampaio et al. 2016). For the statistical analysis, the peak areas of each LC-MS chromatogram in negative ionization mode were used.

With the aim to tentatively identify the constituents of the analyzed extracts by UHPLC-DAD-(ESI)HRMS, we compared the values of the accurate masses and profiles of the UV/Vis absorbance for the peaks detected with the values of compounds available in the literature (Carnevale-Neto et al. 2011; Martucci et al. 2014; Chagas-Paula et al. 2015a,b; Sampaio et al.
2016), our in-house pure compound library AsterDB (Asteraceae Database, http://www.asterbiochem. org/asterdb), and the online databases DNP (Dictionary of Natural Products, http://dnp. chemnetbase.com) and MZedDB (http://maltese.dbs. aber.ac.uk:8888/hrmet/index.html).

Statistical procedures

We used Welch's $t$-test to compare the chemical soil properties of each treatment. The $t$-test was used to test the variations in the number of leaves, leaf area, plant height, length of the taproot, and root and shoot biomass at 30, 45 and 60 DAP. The $t$-test was also used to check for differences in the
Fig. 2 Dry mass basis concentrations of $\mathrm{P}, \mathrm{K}, \mathrm{Ca}$ and $\mathrm{Mg}$ in roots and shoots of Vochysia tucanorum grown on acidic and calcareous soils from the cerrado, 60 days after planting. The box extends from the 25 th to 75 th percentiles, continuous line within the box shows the mean, and error bars represent the 5th and 95th percentiles $(n=3)$. (ns not significant, $* * P<0.01$ using $t$-test)
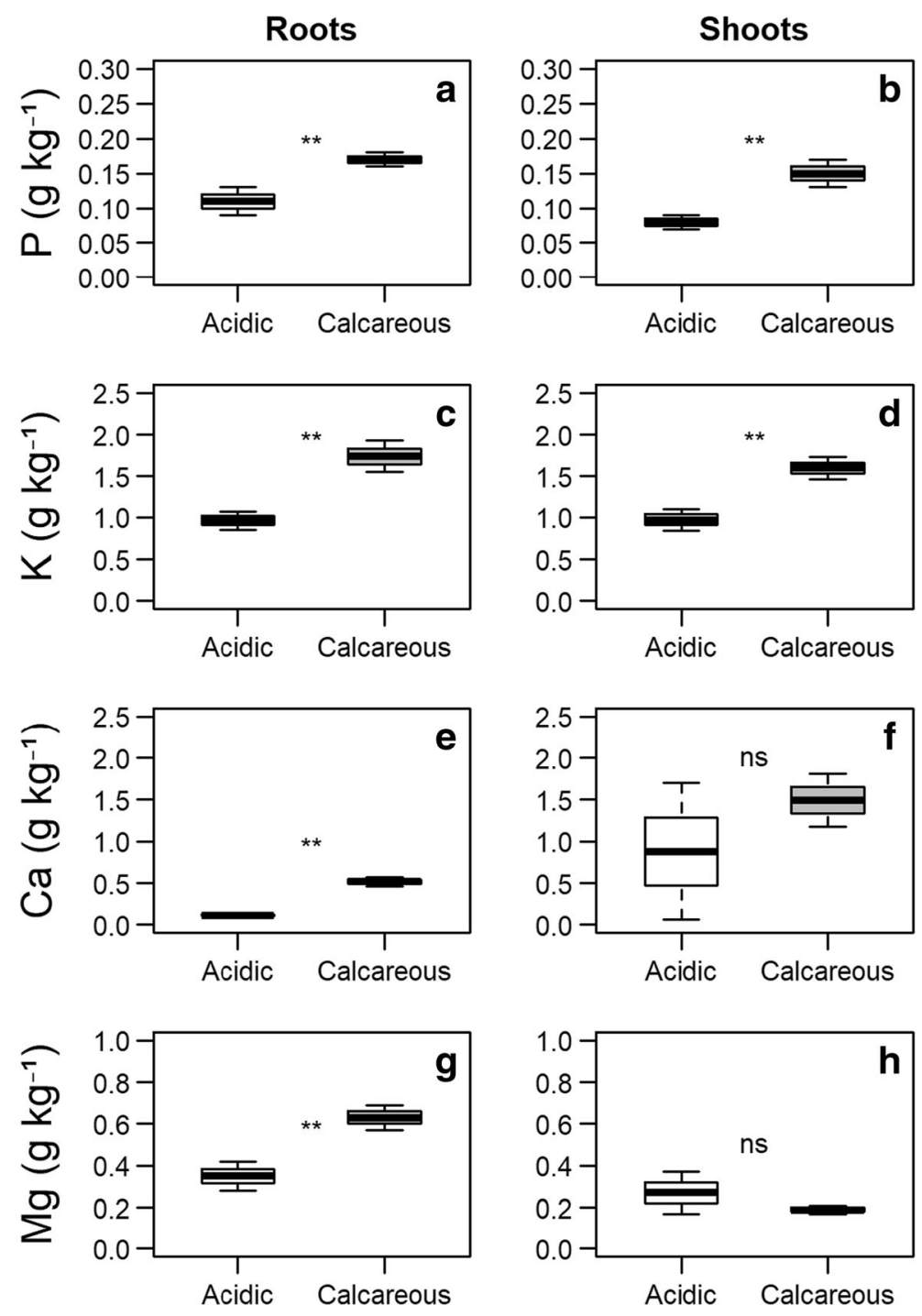
concentrations of $\mathrm{P}, \mathrm{K}, \mathrm{Ca}, \mathrm{Mg}, \mathrm{Fe}, \mathrm{Mn}, \mathrm{Zn}$ and $\mathrm{Al}$ in roots and shoots of plants grown on both soil types at 60 DAP (Zar 2010).

To identify changes in the metabolome of roots and shoots and identify disruptions to the homeostasis of metabolites between plants grown on acidic versus calcareous soil, data were previously transformed using the Pareto transformation and the matrices were analyzed by principal component analysis (PCA) (van den Berg et al. 2006; Sampaio et al. 2016). Statistical procedures were performed using R 3.3.2 ( $\mathrm{R}$ Core Team 2016). PCA was performed using the $\mathrm{R}$ package vegan (Oksanen et al. 2016).

\section{Results}

Plant growth was higher when grown on acidic soil. At 30 DAP, only plants grown on acidic soil had produced leaves, and at $60 \mathrm{DAP}$, these plants had 1.4 times more leaves than those grown on calcareous soil (Table 2). Compared to plants grown on calcareous soil, the leaf area of plants grown on acidic soil was significantly higher throughout the study (Table 2). In addition, plants grown on acidic soil were taller and exhibited higher root and shoot biomasses, especially at 45 and 60 DAP (Table 2). At 30 DAP, although plants from both treatments were approximately the same size, those grown on acidic
Fig. 3 Dry mass basis concentrations of $\mathrm{Al}, \mathrm{Fe}, \mathrm{Zn}$ and $\mathrm{Mn}$ in roots and shoots of Vochysia tucanorum grown on acidic and calcareous soils from the cerrado, 60 days after planting. The box extends from the 25th to 75 th percentiles, continuous line within the box shows the mean, and error bars represent the 5th and 95th percentiles $(n=3)$. (ns not significant, $* * P<0.01$ using $t$-test)
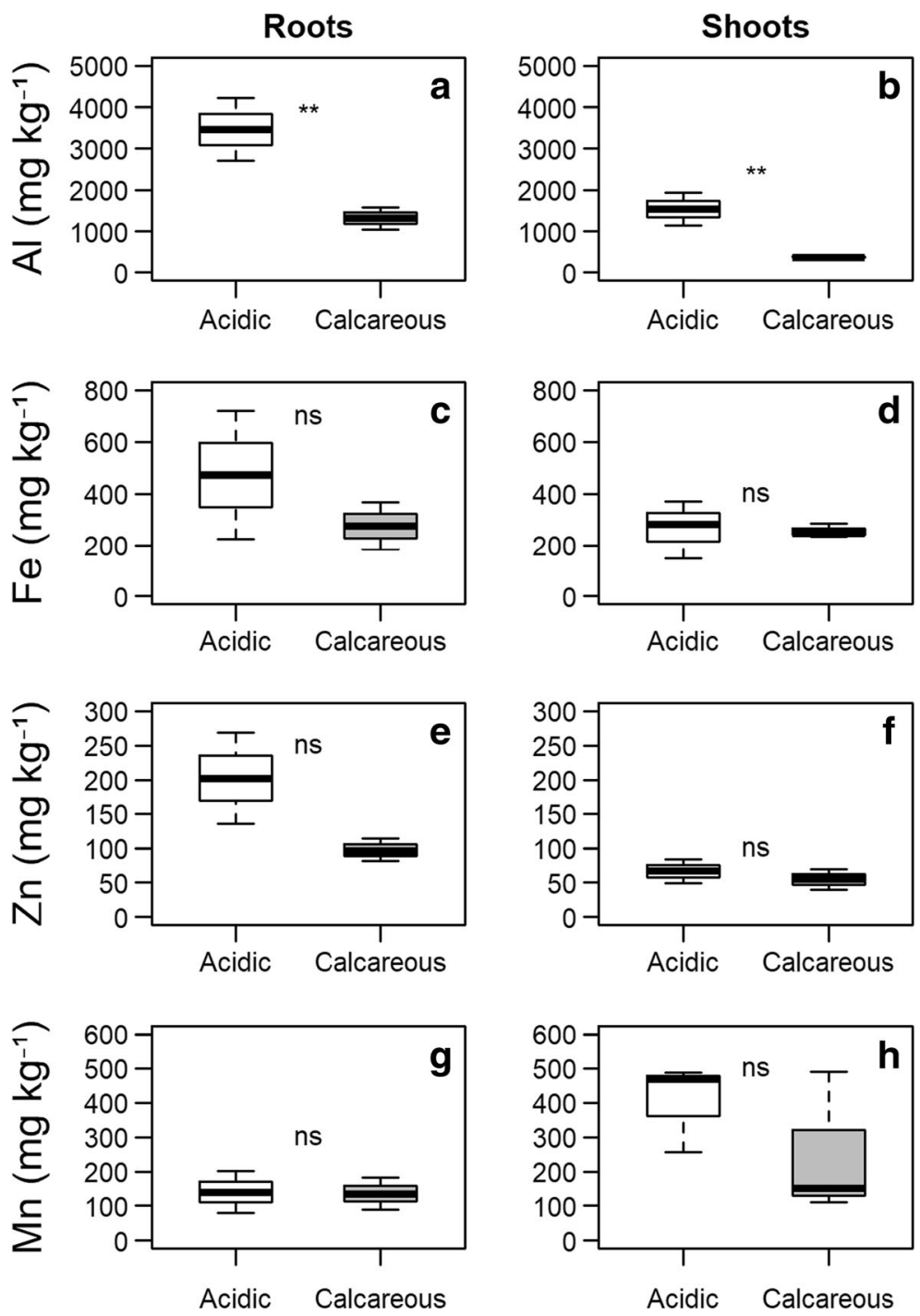
Acidic
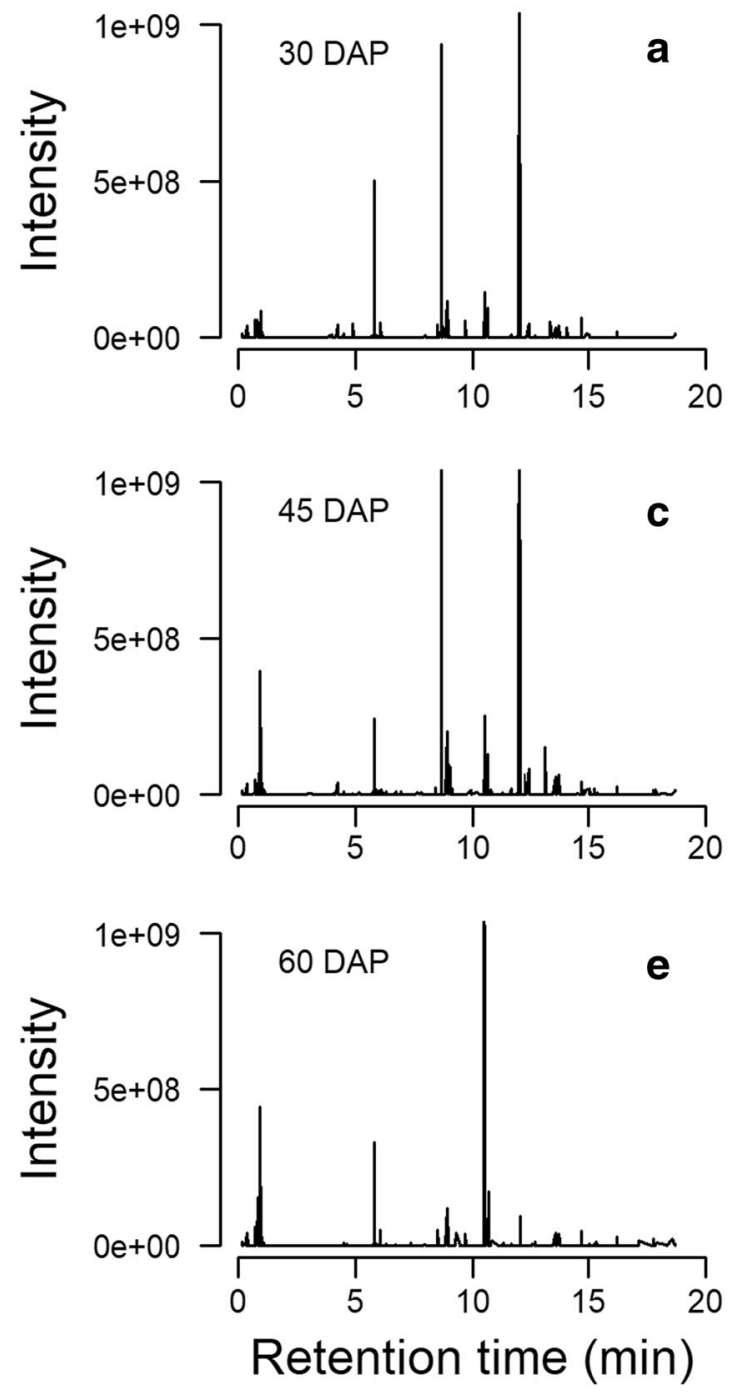

Calcareous
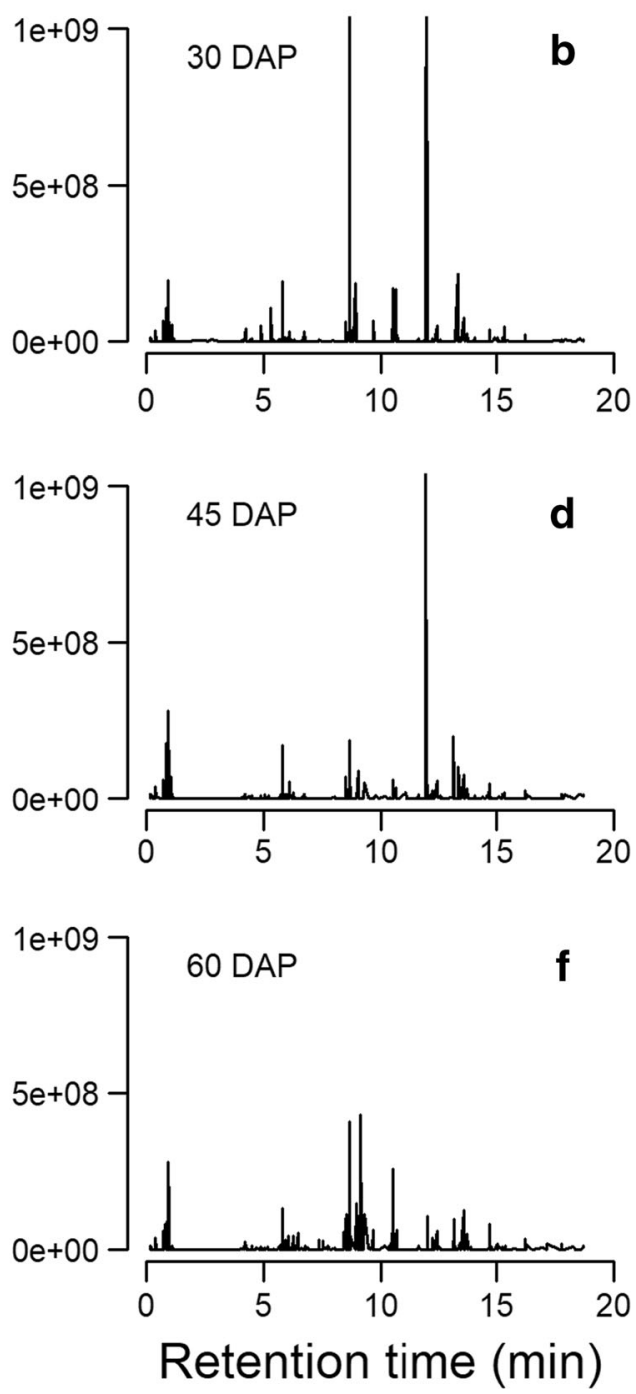

Fig. 4 UHPLC chromatograms of ethanolic extracts of roots of Vochysia tucanorum grown on acidic and calcareous soils from the cerrado obtained at 30, 45 and 60 days after planting (DAP)

soil were more developed; at 45 DAP, plants grown on calcareous soil could be divided into healthy and chlorotic plants; and at 60 DAP, all plants grown on calcareous soil exhibited chlorotic and necrotic leaves. None of the plants grown on acidic soil showed symptoms of a nutritional disorder (Fig. 1).

Despite the reduced development of plants grown on calcareous soil, the roots of these plants showed increased concentrations of P $(+55 \%), \mathrm{K}(+81 \%), \mathrm{Ca}$ $(+364 \%)$ and $\mathrm{Mg}(+77 \%)$ compared to plants grown on acidic soil (Fig. 2). In addition, shoots of plants grown on calcareous soil had $88 \%$ more P (Fig. 2b) and $65 \%$ more $\mathrm{K}$ (Fig. 2d) compared to those grown on acidic soil. On the other hand, compared to plants grown on calcareous soil, plants grown on acidic soil showed $62 \%$ more $\mathrm{Al}$ in roots (Fig. $3 \mathrm{a}$ ) and $+76 \%$ more $\mathrm{Al}$ in shoots (Fig. 3b).

The LC-MS chromatogram of shoot and root extracts reveled different metabolic fingerprinting between plants grown on acidic and calcareous soils (Figs. 4 and 5). The first and second axes of PCA explained together $31 \%$ of the metabolic variation in the root (Fig. 6) and $35 \%$ of the shoot extracts (Fig. 7). After the compound identification procedures by LC-MS and database search, we identified the presence of flavonoids and triterpenoids in roots (Table 3), and 
Acidic
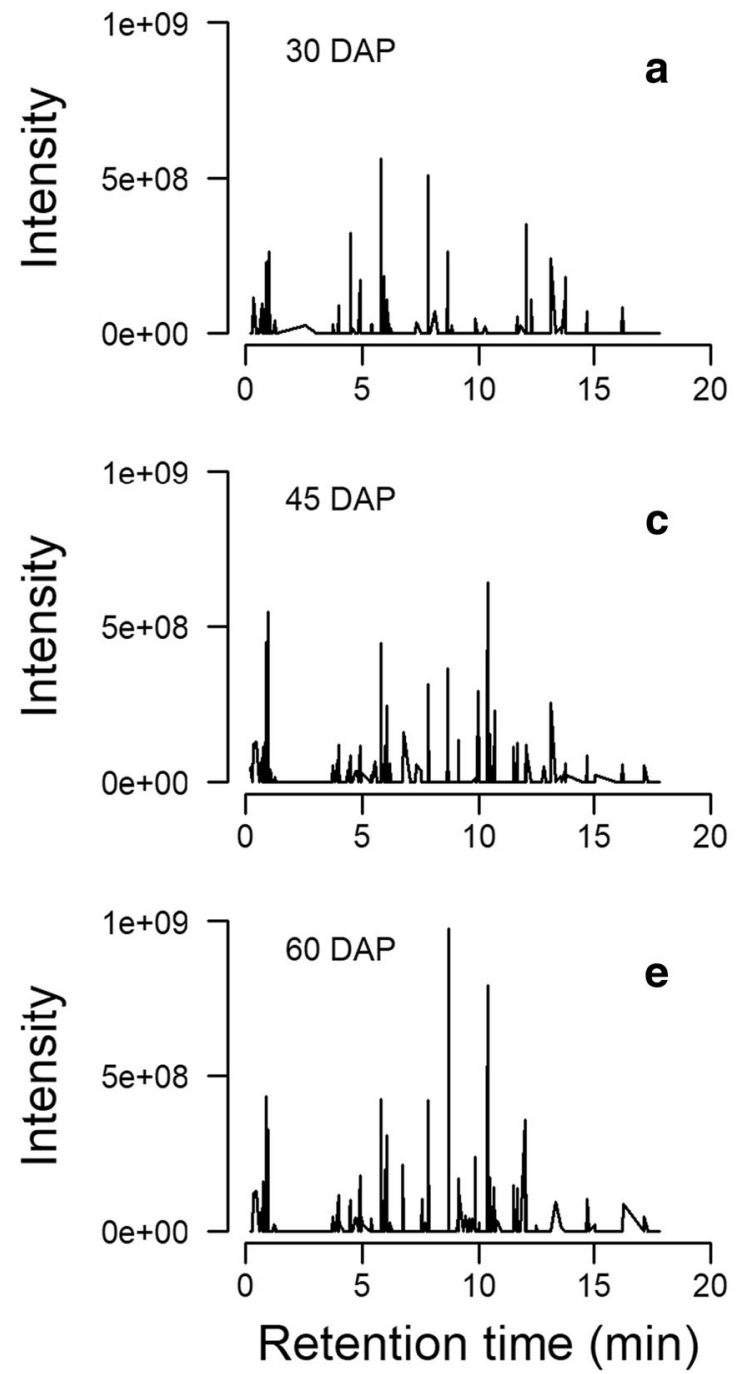

Calcareous
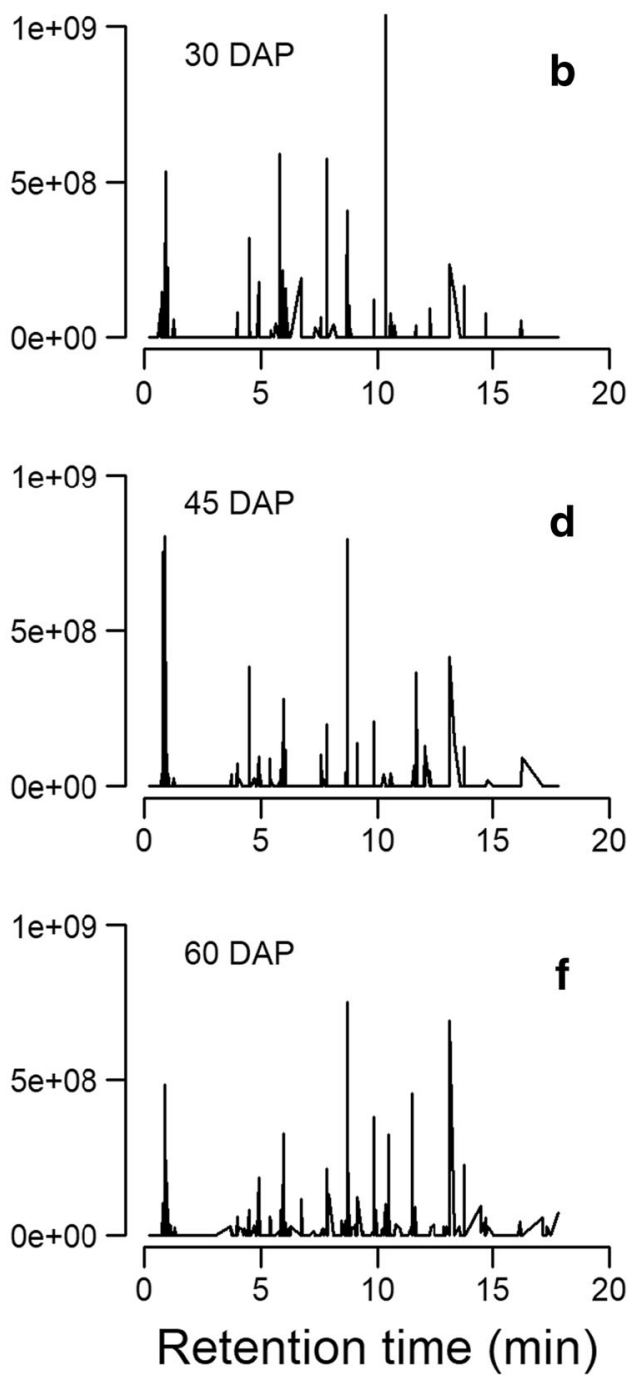

Fig. 5 UHPLC chromatograms of ethanolic extracts of leaves of Vochysia tucanorum grown on acidic and calcareous soils from the cerrado obtained at 30, 45 and 60 days after planting (DAP)

monosaccharides, organic acids, phenolic compounds and flavonoids in shoots (Table 4), with high scores on the PCA.

\section{Discussion}

Plants of $V$. tucanorum grown on calcareous soil were short, showed reduced biomass and leaf number, and exhibited metabolomic changes in multiple pathways as evidenced by the compounds identified in the high PCA scores. These characteristics are indicative of calcifuge species (Lee 1998). Calcifuge behavior has already been observed in Miconia albicans Steud and Vochysia thyrsoidea Pohl, two Al-accumulating plants from the cerrado (Haridasan 1988; Haridasan 2008), as well as in grasses (Corynephorus canescens (L.) P. Beauv., Deschampsia flexuosa (L.) Trin. and Holcus mollis L.) and herbs (Digitalis purpurea L., Lychnis viscaria L., Rumex acetosella L., Scleranthus annuus L. and Silene rupestris L.) (Zohlen and Tyler 2004) from dry meadows and bedrocks in Sweden (Tyler 1996; Tyler 2000).

Calcifuge species grown on calcareous soil frequently show symptoms of nutrient deficiency (e.g., P, K and Fe) (Lee 1998), demonstrating that these species do not tolerate calcareous soil. Despite the symptoms of 


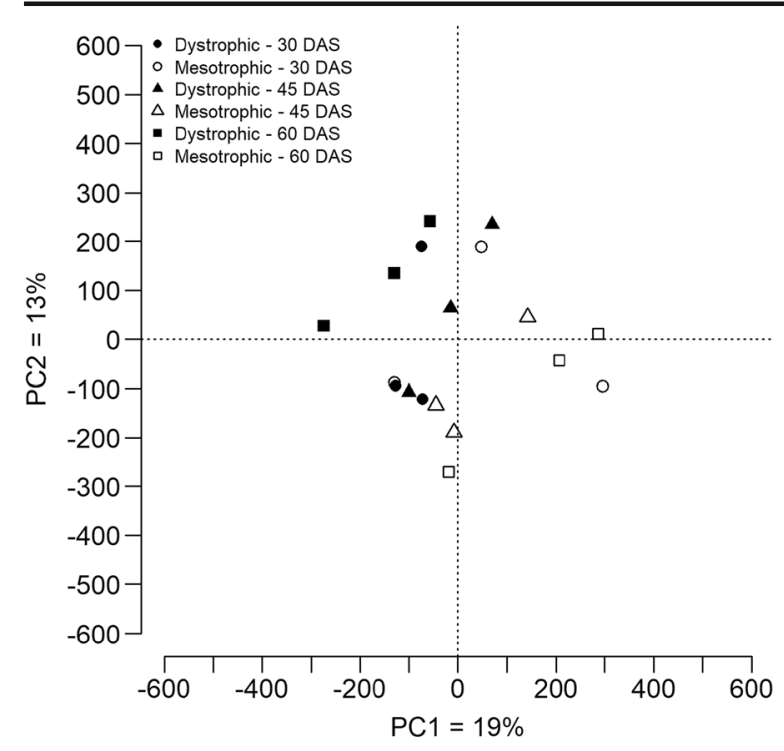

Fig. 6 Plot of the first (PC1) and second (PC2) principal components of the root metabolite fingerprinting of Vochysia tucanorum grown on acidic and calcareous soils from the cerrado at 30,45 and 60 days after planting. $(n=3)$

nutritional disorders (short plants with less and small yellow leaves) observed in plants grown on calcareous soils (Table 2; Fig. 1), the plants of the present study showed higher concentrations of $\mathrm{P}, \mathrm{K}, \mathrm{Ca}$ and $\mathrm{Mg}$ in their roots and $\mathrm{P}$ and $\mathrm{K}$ in their shoots in relation to plants grown in acidic soil (Fig. 2). Therefore, $\mathrm{Ca}$ and $\mathrm{Mg}$ concentrations in the leaves of $V$. tucanorum do not reflect $\mathrm{Ca}$ and $\mathrm{Mg}$

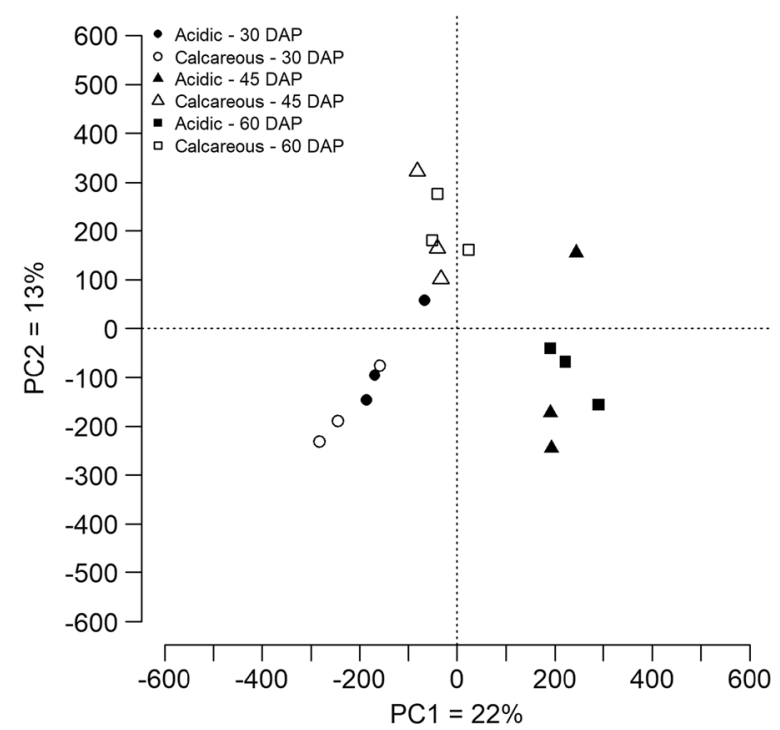

Fig. 7 Plot of the first (PC1) and second (PC2) principal components of the shoot metabolite fingerprinting of Vochysia tucanorum grown on acidic and calcareous soils from the cerrado at 30,45 and 60 days after planting $(n=3)$ availability in the calcareous soil, which had 38 times more $\mathrm{Ca}$ and 19 times more $\mathrm{Mg}$ when compared to the acidic soil. The calcifuge behavior and nutritional disorders of M. albicans has been attributed to $\mathrm{Ca}$-induced $\mathrm{Fe}$ chlorosis and $\mathrm{Mn}$ toxicity in calcareous soil since the concentrations of Fe and $\mathrm{Mn}$ are higher in these plant species grown on calcareous soil (Haridasan, 1988). However, in the present study, the root and shoot concentrations of $\mathrm{Fe}$ and $\mathrm{Mn}$ were similar between plants grown on acidic and calcareous soil (Fig. 3c-h). Considering nutrients transported to the shoots, only P (Fig. 2b) and K (Fig. 2d) could have caused toxicity in plants grown on calcareous soil, which showed one-fold higher concentrations of these nutrients in their leaves in relation to those of plants grown on acidic soil. Nutritional studies using seedlings of Vochysiaceae species from the cerrado are extremely rare. However, in leaves of adult woody plants from cerrado communities, including Vochysiaceae species, the leaf $\mathrm{P}$ concentration is 10 times higher and $\mathrm{K}$ is similar to the values observed in the present study (Souza et al. 2015b, c). Therefore, it is unlikely that $\mathrm{P}$ or $\mathrm{K}$ could have caused the nutritional disorders in plants of the present study grown in calcareous soil.

In the present study, soil fertility was not similar between the calcareous and acidic soil, and there was no contrast in the availability of a specific nutrient. Distinct macro- and micronutrient availability varies considerably between these two soils (Table 1). This same difficulty was faced by Haridasan (1988) when studying Al-accumulating species because soil is a complex matrix, making it difficult to establish a contrast of only one nutrient. Notwithstanding, despite the fact that plants grown in calcareous soil accumulated more $\mathrm{P}, \mathrm{K}$, $\mathrm{Ca}$ and $\mathrm{Mg}$ in the roots and $\mathrm{P}$ and $\mathrm{K}$ in shoots in relation to plants grown on acidic soil, it is noteworthy that $\mathrm{Al}$ was more than three times higher in shoots and roots of plants grown on acidic soil when compared to those grown on calcareous soil (Fig. 3a,b). In addition, $\mathrm{Ca}$ and $\mathrm{Mg}$ was significantly higher in roots of plants grown on calcareous soil in relation to those grown on acidic soil (Fig. 2e,g), but in the leaves the concentration of these nutrients were similar between treatments (Fig. 2f,h). Therefore, $V$. tucanorum limits leaf absorption of $\mathrm{Ca}$ and $\mathrm{Mg}$ and for some reason these elements are retained in its roots, while $\mathrm{Al}$, when available (acidic soil), are absorbed and accumulated by both roots and leaves (Fig. 3a,b). This evidence suggests a calcifuge behavior for this species. 
Table 3 Measured masses $(\mathrm{m} / \mathrm{z})$ on the negative ionization mode $[\mathrm{M}-\mathrm{H}]^{-}$, retention times and scores on the first $(\mathrm{PC} 1)$ and second (PC2) principal components of the 10 most significant compounds

\begin{tabular}{|c|c|c|c|c|c|c|}
\hline Suggested compound & $\begin{array}{l}\text { Isotope } \\
\text { Formula }\end{array}$ & Class & $m / z$ & $\begin{array}{l}\text { Retention } \\
\text { time (min) }\end{array}$ & $\begin{array}{l}\text { PC1 } \\
\text { score }\end{array}$ & $\begin{array}{l}\mathrm{PC} 2 \\
\text { score }\end{array}$ \\
\hline \multirow[t]{12}{*}{ Geraldone-7-O-glucoside } & \multirow[t]{12}{*}{$\mathrm{C}_{22} \mathrm{H}_{22} \mathrm{O}_{10}$} & \multirow[t]{12}{*}{ Flavonoid } & 387.1150038 & 0.83 & -31.43 & \\
\hline & & & 248.9833908 & 0.91 & 33.06 & \\
\hline & & & 455.1119563 & 5.79 & 34.05 & \\
\hline & & & 465.1404877 & 5.79 & -30.35 & 42.33 \\
\hline & & & 728.3941284 & 8.65 & & 114.00 \\
\hline & & & 729.3969238 & 8.66 & & -26.97 \\
\hline & & & 766.4016705 & 8.67 & 44.26 & -27.66 \\
\hline & & & 795.3784248 & 8.68 & & -22.32 \\
\hline & & & 711.3963623 & 10.50 & -82.12 & 32.58 \\
\hline & & & 680.3737488 & 10.66 & & 29.30 \\
\hline & & & 679.3704529 & 10.67 & & -43.50 \\
\hline & & & 565.3385533 & 11.95 & 81.16 & \\
\hline Bellericagenin B; or Trachelosperogenin B & $\mathrm{C}_{30} \mathrm{H}_{48} \mathrm{O}_{7}$ & Triterpenoid & 519.3331792 & 12.01 & 151.95 & 112.92 \\
\hline \multirow{3}{*}{$\begin{array}{l}\text { 24-Hydroxytormentic acid; Bellericagenin } \\
\text { A; or Sericic acid }\end{array}$} & \multirow[t]{3}{*}{$\mathrm{C}_{30} \mathrm{H}_{48} \mathrm{O}_{6}$} & \multirow[t]{3}{*}{ Triterpenoid } & 503.3386520 & 13.15 & & \multirow[t]{3}{*}{25.72} \\
\hline & & & 661.3601155 & 13.59 & 34.36 & \\
\hline & & & 1007.683136 & 14.69 & 29.75 & \\
\hline
\end{tabular}

in the root metabolite fingerprinting of Vochysia tucanorum grown on acidic and calcareous soils from the cerrado $(n=3)$ 
In the present study, roots and shoots of $V$. tucanorum seedlings accumulated 3000 and $1500 \mathrm{mg} \mathrm{Al} \mathrm{per} \mathrm{kg} \mathrm{dry}$ mass, respectively (Fig. 3a,b). These values are in accordance with previous observations for Vochysiaceae plants (e.g. Vochysia, Qualea and Callisthene spp) (Haridasan and Araújo 1988; Souza et al. 2015b, Bressan et al. 2016) and, therefore, confirmed the Alaccumulating behavior of this species (Chenery 1948) even during its early development phase. However, what these previous studies could not test was the responses of these $\mathrm{Al}$-accumulating adult plants when grown on calcareous soil.

Therefore, as a calcifuge species, it seems that $\mathrm{Ca}$ and $\mathrm{Mg}$, when available (calcareous soil), are retained in its roots and, when not available (acidic soil), the Al is significantly absorbed (much more than $\mathrm{Ca}$ and $\mathrm{Mg}$ are when available in calcareous soil) and plants develop better, reinforcing its $\mathrm{Al}$-accumulating behavior. It is not possible to claim that the lack of $\mathrm{Al}$ in the calcareous soil caused the nutritional disorder as evidenced in Fig. 1 because comparison of soil analysis across different soils is problematical and this merits further investigation (using contrasting nutrient solution, for example). However, if $\mathrm{Al}$ has an impact in plant development for $V$. tucanorum it might have other metabolic consequences.

Establishment, survival and growth of $V$. tucanorum seedlings are critical, and here we demonstrate that this species goes through adjustments when grown on calcareous or acidic soil. We putatively identified flavonoids, triterpenoids, monosaccharides, organic acids and other phenolics and observed whether their amounts were increased or decreased in plants grown on acidic and calcareous soils. Despite this observation based on the chromatograms, our metabolomic approach does not allow compound quantification, thus providing a semiquantitative analysis based on the shape and peak area (Sampaio et al. 2016).

Flavonoids, triterpenoids and other phenolics are usually associated with defense mechanisms (Sampaio et al. 2016), especially against herbivores, whose pressure on plants is important in the Cerrado (Kursar et al. 1999; Silva and Batalha 2011). Organic acids, especially those secreted by roots of species that are tolerant to $\mathrm{Al}$, have been widely explored in the literature, stimulating revisions about the theme (Ryan et al. 2011; Brunner and Sperisen 2013). Despite the solid information about the metabolism of malate, citrate and oxalate in Alaccumulating species grown under low and high $\mathrm{Al}$ availability (Shen and Ma 2001; Watanabe and Ozaki
2001; Morita et al. 2004; Horst et al. 2010), little attention has been devoted to other metabolites that are affected by contrasting fertility conditions. Therefore, the fact that the plants grown on calcareous soil showed a different metabolomic profile in relation to that of plants grown on acidic soil could indicate that these contrasting fertility conditions could affect their regular growth and survival. Thus, these compounds could have the potential to be biomarker targets that could be used in future studies to study the metabolism of $\mathrm{Al}$-accumulating species from the Cerrado.

\section{Conclusions}

This is the first metabolite fingerprinting investigation using UHPLC-DAD(ESI)-HRMS to confirm adjustments in the metabolome of $V$. tucanorum grown on calcareous soil. In addition, we confirm that $V$. tucanorum is an Alaccumulating species from the Cerrado and that its calcifuge behavior is evidenced by nutritional disorders when cultivated on calcareous soil.

Acknowledgements MCS acknowledges the São Paulo Research Foundation (FAPESP) for the post-doctoral fellowship (grant \#2013/21293-6). FBC acknowledges FAPESP (grants \#2010/51454-3 and \#2014/26866-7) and Brazilian National Council for Scientific and Technological Development (CNPq, grant \#304905/2015-1) for financial support. GH acknowledges CNPq for a research productivity fellowship (grant \#308902/2014-9). Authors thank Mr. João D. Giudice Neto, Mr. Benedito C. de Souza and Mr. Mateus C. de Souza for assistance in the field trips, to Prof. Pedro L.C.A. Alves for lending us a greenhouse at FCAVUNESP, and to Prof. Pax Blamey and Prof. Mundayatan Haridasan for the editorial advices on the previous version of the manuscript. The authors thank Estação Ecológica de Mogi Guaçu for logistic support, and the anonymous reviewers for their comments, which highly improved the presentation of this manuscript.

\section{References}

Banhos OFAA, Carvalho BMO, da Veiga EB, Bressan ACG, Tanaka FAO, Habermann G (2016a) Aluminum-induced decrease in $\mathrm{CO}_{2}$ assimilation in 'Rangpur' lime is associated with low stomatal conductance rather than low photochemical performances. Scie Hort 205:133-140

Banhos OFAA, Souza MC, Habermann G (2016b) High aluminum availability may affect Styrax camporum, an Al nonaccumulating species from the Brazilian savanna. Theor Exp Plant Physiol 28:321-332

Barbosa AR, Yamamoto K, Valio IFM (1999) Effect of light and temperature on germination and early growth of Vochysia 
tucanorum Mart., Vochysiaceae, in cerrado and forest soil under different radiation levels. Rev Bras Bot 22:275-280

Bressan ACG, Coan AI, Habermann G (2016) X-ray spectra in SEM and staining with chrome azurol $\mathrm{S}$ show $\mathrm{Al}$ deposits in leaf tissues of Al-accumulating and non-accumulating plants from the cerrado. Plant Soil 404:293-306

Brunner I, Sperisen C (2013) Aluminum exclusion and aluminum tolerance in woody plants. Front Plant Scie 4:1-12

Carnevale-Neto F, Pilon AC, Silva DHS, Bolzani VS, CastroGamboa I (2011) Vochysiaceae: secondary metabolites, ethnopharmacology and pharmacological potential. Phytochem Rev 10:413-429

Chagas-Paula D, Oliveira T, Tong Z, Edrada-Ebel R, Da Costa F (2015a) Prediction of anti-inflammatory plants and discovery of their biomarkers by machine learning algorithms and metabolomic studies. Planta Med 81:450-458

Chagas-Paula D, Tong Z, Da Costa F, Edrada-Ebel R (2015b) A Metabolomic approach to target compounds from the Asteraceae family for dual COX and LOX inhibition. Meta 5:404-430

Chenery EM (1948) Aluminium in the plant world. Part I: general survey in dicotyledons. Kew Bullet 3:173-183

Fukusaki E, Kobayashi A (2005) Plant metabolomics: potential for practical operation. J Biosci Bioeng 100:347-354

Haridasan M (1982) Aluminium accumulation by some cerrado native species of central Brazil. Plant Soil 65:265-273

Haridasan M (1988) Performance of Miconia albicans (Sw.) Triana, an aluminium-accumulating species, in acidic and calcareous soils. Comm Soil Scien Plant Anal 19:1091-1103

Haridasan M (2008) Nutritional adaptations of native plants of the cerrado biome in acid soils. Braz J Plant Physiol 20:183-195

Haridasan M, Araújo GM (1988) Aluminium-accumulating species in two forest communities in the cerrado region of central Brazil. Forest Ecol Manag 24:15-26

Horst WJ, Wang Y, Eticha D (2010) The role of the root apoplast in aluminium-induced inhibition of root elongation and in aluminium resistance of plants: a review. Ann Bot 106:187-197

Kochian LV, Hoekenga OA, Piñeros MA (2004) How do crop plants tolerate acid soils? Mechanisms of aluminum tolerance and phosphorous efficiency. Annu Rev Plant Biol 55:459493

Kochian LV, Piñeros MA, Liu J, Magalhaes JV (2015) Plant adaptation to acid soils: the molecular basis for crop aluminum resistance. Annu Rev Plant Biol 66:571-598

Kopittke PM, Blamey FPC, Menzies NW (2008) Toxicities of Al, $\mathrm{Cu}$, and $\mathrm{La}$ include ruptures to rhizodermal and root cortical cells of cowpea. Plant Soil 303:217-227

Kursar TA, Coley PD, Corley DG, Gupta MB, Harrison LA, Ortega-Barría E, Windsor DM (1999) Ecologically guided bioprospecting in Panama. Pharm Biol 37:114-126

Lee JA (1998) The calcicole-calcifuge problem revisited. Adv Bot Res 29:1-30

Martucci MEP, de Vos RCH, Carollo CA, Gobbo-Neto L (2014) Metabolomics as a potential chemotaxonomical tool: application in the genus Vernonia schreb. PLoS One 9:e93149

Metali F, Salim KA, Burslem DFRP (2012) Evidence of foliar aluminium accumulation in local, regional and global datasets of wild plants. New Phytol 193:637-649

Morita A, Horie H, Fujii Y, Takatsu S, Watanabe N, Yagi A, Yokota H (2004) Chemical forms of aluminum in xylem sap of tea plants (Camellia sinensis L.) Phytochemistry 65: 2775-2780

Obata T, Fernie AR (2012) The use of metabolomics to dissect plant responses to abiotic stresses. Cell Mol Life Sci 69: 3225-3243

Oksanen J, Blanchet FG, Friendly M, Kindt R, Legendre P, McGlinn D, Minchin PR, O'Hara RB, Simpson GL, Solymos P, Stevens MHH, Szoecs E, Wagner H (2016) Vegan: community ecology package. R package version 2: 4-1 https://CRAN.R-project.org/package=vegan. Accessed 16 January 2017

Pluskal T, Castillo S, Villar-Briones A, Orešič M (2010) MZmine 2: modular framework for processing, visualizing, and analyzing mass spectrometry-based molecular profile data. BMC Bioinfo 11:395

R Core Team (2016) R: A language and environment for statistical computing. R Foundation for Statistical Computing, Vienna, Austria. URL https://www.R-project.org/. Accessed 16 January 2017

Raij B, van Quaggio JA, Cantarella H, Ferreira ME, Lopes AS, Bataglia OC (1987) Análise química do solo para fins de fertilidade. Fundação Cargill, Campinas

Ratter JA, Bridgewater S, Ribeiro JFR (2003) Analysis of floristic composition of the Brazilian cerrado vegetation. III: comparison of the woody vegetation of 376 areas. Ed J Bot 60:57109

Ryan PR, Tyerman SD, Sasaki T, Furuichi T, Yamamoto Y, Zhang WH, Delhaize E (2011) The identification of aluminiumresistance genes provides opportunities for enhancing crop production on acid soils. J Exp Bot 62:9-20

Sampaio BL, Ruangelie EE, da Costa FB (2016) Effect of the environment on the secondary metabolic profile of Tithonia diversifolia: a model for environmental metabolomics of plants. Sci Rep 6:29265

Schmitt M, Watanabe T, Jansen S (2016) The effects of aluminium on plant growth in a temperate and deciduous aluminium accumulating species. AoB PLANTS 8: plw065

Shen R, Ma JF (2001) Distribution and mobility of aluminum in an al-accumulating plant, Fagopyrum esculentum Moench. J Exp Bot 52:1683-1687

Silva DM, Batalha MA (2011) Defense syndromes against herbivory in a cerrado plant community. Plant Ecol 212:181193

Simirgiotis MJ, Quispe C, Areche C, Sepúlveda B (2016) Phenolic compounds in Chilean mistletoe (Quintral, Tristerix tetrandus) analyzed by UHPLC-Q/Orbitrap/MS/MS and its antioxidant properties. Molecules 21:245

Souza MC, Amaral CL, Habermann G, Alves PLCA, da Costa FB (2015a) Non-destructive model to estimate the leaf area of multiple Vochysiaceae species. Braz J Bot 38:903-909

Souza MC, Bueno PCP, Morellato LPC, Habermann G (2015b) Ecological strategies of al-accumulating and nonaccumulating functional groups from the cerrado sensu stricto. An Acad Bras Cienc 87:813-823

Souza MC, Franco AC, Haridasan M, Rossatto DR, Araújo JF, Morellato LPC, Habermann G (2015c) The length of the dry season may be associated with leaf scleromorphism in cerrado plants. An Acad Bras Cienc 87:1691-1699

Tyler G (1996) Soil chemistry and plant distributions in rock habitats of southern Sweden. Nord J Bot 16:609-635 
Tyler G (2000) Integrated analysis of conditions accounting for intersite distribution of grassland plants. Nord J Bot 20:485500

USDA - United States Department of Agriculture (1999) Soil taxonomy: a basic system of soil classification for making and interpreting soil surveys. Washington, USDA, 870p

Van den Berg RA, Hoefsloot HCJ, Westerhuis JA, Smilde AK, van der Werf MJ (2006) Centering, scaling, and transformations: improving the biological information content of metabolomics data. BMC Genomics 7:142

von Uexküll HR, Mutert E (1995) Global extent, development and economic impact of acid soils. In: Date RA et al (eds) Plant soil interactions at low pH. Kluwer Academic Publ, Dordrecht, pp 5-19

Watanabe T, Osaki M (2001) Influence of aluminum and phosphorus on growth and xylem sap composition in Melastoma malabathricum L. Plant Soil 237:63-70

Wolfender JL, Rudaz S, Choi YH, Kim HK (2013) Plant metabolomics: from holistic data to relevant biomarkers. Cur Med Chem 20:1056-1090

Zar JH (2010) Biostatistical analysis, 5th edn. Prentice Hall, Upper Saddle River

Zohlen A, Tyler G (2004) Soluble inorganic tissue phosphorus and calcicole-calcifuge behaviour of plants. Ann Bot 94:427-432 